\title{
PENTATONIIKAN KÄSITE 1900-LUVUN ALUN SUOMALAISESSA MUSIIKINTUTKIMUKSESSA
}

Erilaiset pentatoniset säveljärjestelmät ovat olleet keskeisiä Euroopan ulkopuolisten musiikkien rakenneanalyysissa 1800-luvun lopulta lähtien. Tämän päivän musiikintutkijoille ja muusikoille pentatoniikka on tuttu hyvin monenlaisista musiikeista, aina Béla Bartókin sävellyksistä blues-musiikkiin ja Pohjois-Amerikan alkuperäisväestön lauluihin, puhumattakaan Kiinan, Japanin ja Kaakkois-Aasian musiikeista. Musiikkitietosanakirjoissa, koulukirjoissa ja musiikkioppilaitosten oppikirjoissa pentatoniikka määritellään tavallisesti sangen lakonisesti viisisävelisenä asteikkona:

\footnotetext{
Pentatoninen asteikko, viisisävelinen asteikko, joka eri muodoissa tavataan hyvin monien eri kansojen musiikeissa. Useimmiten pentatonisella asteikolla viitataan sellaiseen viisisäveliseen asteikkoon, jossa ei ole puolisävelaskelia, esim. c d e g a; tätä tyyppiä edustaa myös pianon mustien koskettimien muodostama pentatoninen asteikko. (Sävelten maailma V 1994: 218.)
}

Pentatoniset säveliköt - samoin kuin kirkkosävellajien mukaan nimetyt modaaliset säveliköt sekä duuri ja molli - ovat muodostuneet eräänlaisiksi karkean tason hahmotusvälineiksi, joilla on tyypitelty eri puolilta maailmaa kotoisin olevia melodioita. Tällainen analyysi voidaan määritellä eräänlaiseksi kulttuurisesti vapaiden sävelikköjen menetelmäksi. Universaaleiksi ja kulttuurien rajat ylittäviksi määritellyt sävelikkörakenteet tunnistetaan ja ikään kuin täytetään tutkittavaan musiikkikulttuuriin liittyvällä kontekstilla (ks. esim. Nettl 1956; Sachs 1962).

Pentatoniikan keskeinen oppihistoriallinen ongelma on se, että ilmiönä se liittyy moneen erilaiseen historialliseen musiikkikulttuuriin. Pentatoniikka on samanaikaisesti käsite sekä tutkimuksessa että esimerkiksi koulujen ja musiikkioppilaitosten opetuksessa. Esimerkiksi Aarre Joutsenvirran ja Jari Perkiömäen (2008) kirjoittamilla Sibelius-Akatemian Musiikinteoria 1/ Asteikot ja soinnut-internetsivuilla pentatoniset asteikot esitellään seuraavasti: 
Yleisimmät pentatoniset asteikot ovat duuripentatoninen - -, joka on kuin duuriasteikko, jossa puoliaskelet on korvattu pienellä terssillä sekä mollipentatoninen - -, joka voidaan nähdä paitsi molliasteikon myös ns. blues-asteikon perusrakenteena.

Pentatonisia asteikkoja pidetään yleisesti vanhimpina säveljärjestelmän perustana olevina asteikkorakenteina, joista monet useampisäveliset asteikot ovat vähitellen muodostuneet.

Pentatoniikka on siis usein tulkittu vanhakantaiseksi säveljärjestelmäksi, joka on edeltänyt sekä eurooppalaista duuri-molli-tonaalista että modaalista järjestelmää. 1900-luvun alun tutkimuksessa pentatoniikka yhdistetään erityisesti "primitiivisten" kansojen musiikkeihin, vaikka myös eurooppalaisessa taidemusiikissa on käytetty pentatoniikkaa. (Day-O'Connell 2002: 316.)

Käytännössä myös jokainen esimerkiksi sähkökitaralla rockmusiikkia soittanut on joutunut tutustumaan pentatonisiin skaaloihin. Pentatoniikka on siten tuttua, konkreettista ja sen tunnistaminen on helppoa, koska useimmilla musiikintutkijoilla on jo valmiina ajatuksellinen ja kokemuksellinen malli pentatoniikalle. Usein sekä tutkimusten tekijöiden että niiden lukijoiden asiaan liittyvä yleisen tason ja monista erilaisista lähteistä opittu esiymmärrys vaikuttaa merkittävästi siihen, millaiseksi käsitteeksi pentatoniikka hahmottuu. Sama ilmiöhän pätee myös duuri- ja mollisävellajeihin, mutta niiden kohdalla on käsitelty paljon kysymystä eurooppalaisen ihmisen musiikin hahmottamisen etnosentrisyydestä.

Pentatoniikkaan liittyvä oppihistoriallinen tutkimus on varsinkin Suomessa jäänyt varsin suppeaksi verrattuna siihen, kuinka yleisesti sitä on käytetty niin kotimaisessa kuin ulkomaisessa tutkimuksessa (Jouste 2001b). Kauko-Idän musiikkikulttuureissa kuten esimerkiksi Kiinassa, Japanissa (gagaku-perinne) ja Jaavalla (gamelan-musiikin sléndro-viritys) pentatoniikkaa on käsitelty teoreettisesti. Eurooppalaisessa tutkimuksessa käytössä olevat puolisävelaskeleettomat eli anhemitoniset pentatoniset säveliköt ovatkin juuri näitä itäisistä musiikkikulttuureista tuttuja pentatonisia sävelikköjä, mutta vailla niihin liittyvää itämaista teorianmuodostusta. (Day-O'Connell 2002: 315.)

1900-luvun alun eurooppalaisessa tutkimuksessa pentatoniikkaan liittyi kuitenkin sangen selkeä teoreettinen määrittely. Tarkastelenkin sitä, miten pentatoniikka-käsite tuli tunnetuksi suomalaisessa kansanmusiikintutkimuksessa, erityisesti 1900-luvun ensimmäisten vuosikymmenten aikana. Tuolloin vaikuttivat niin sanotun suomalaisen koulukunnan kolme merkittävää tutkijaa: Ilmari Krohn (1867-1960), Armas Launis (1884-1954) ja A. O. Väisänen (1890-1969). He kaikki käsittelivät pentatoniikkaa 
kirjoituksissaan. Pentatoniikan oppihistorian tarkastelu auttaa myös ymmärtämään niitä piirteitä, jotka usein liitetään pentatoniikkaan, mutta joita ei suinkaan aina määritellä täsmällisesti. Yksi näistä piirteistä on ajatus pentatoniikan vanhakantaisuudesta. Voidaan myös kysyä, mitä laajempia maailman eri kulttuureihin ja varsinkin 1900-luvun alun suomalaisten tutkijoiden omaan kulttuuriin liittyviä asioita tarkasteltiin heidän kirjoituksissaan ja miten pentatoniikka kytkeytyi niihin.

\section{Pentatoniikka 1800-luvun musiikinteorioissa ja musiikinhistorian esityksissä}

1800-luvulla tunnetuimmat pentatonisiksi määritellyt säveljärjestelmät liittyivät Kiinan ja Japanin musiikkeihin. Näissä käytettyjä asteikkoja kuvailtiin "kiinalaisina", "aukollisina" tai "vajaina" ennen kuin niihin sovellettiin varsinaisesti pentatoniikkatermiä. Euroopassa pentatonisia piirteitä havaittiin skotlantilaisessa ja irlantilaisessa kansanmusiikissa. Ensimmäisen kerran pentatoniikka-termiä käytti musiikintutkimuksessa saksalainen musikologi Carl Engel "kaikkein muinaisimpien kansojen" eli erityisesti assyyrialaisten, egyptiläisten ja heprealaisten musiikkia käsitelleessä teoksessaan vuonna 1864. Engel viittasi pentatoniikalla sekä itämaisiin asteikkoihin että länsimaisessa taidemusiikissa käytettyihin asteikkoihin, jotka olivat duuri-mollitonaliteettiin verrattuna vajaita tai aukollisia. (Day-O'Connell 2001: 315.)

1800-luvun lopun musiikintutkijoilla oli käytettävissä ulkoeurooppalaisten musiikkien lähteitä varsin rajallisesti. Tutkimuksia tehtiin lähinnä kirjallisten nuottiesimerkkien pohjalta. Harvoilla musiikinteoreettisia kysymyksiä pohtineilla tutkijoilla oli omakohtaisia kokemuksia Euroopan ulkopuolisista musiikeista. Samaan aikaan eurooppalaisten tutkijoiden, kuten esimerkiksi Richard Wallaschekin, Herbert Spencerin ja hieman myöhemmin erityisesti niin sanotun Berliinin koulukunnan musiikinteoreettisissa pohdinnoissa yleistyi universaaliin evoluutio-oppiin pohjaava ajattelu. Oma erityinen keskustelunaihe liittyi pohdintaan siitä, miten musiikki ylipäätään oli saanut alkunsa (esim. Spencer 1890; Wallaschek \& Cattell 1891; Wallaschek 1970).

Musiikin asteikkorakenteiden avulla tarkasteltiin tutkittavan musiikin kehitysvaihetta, ja pentatoniikkaa pidettiin sekä musiikin varhaisvaiheille että yleisesti alemmille kehitysasteille tyypillisenä piirteenä. 
1800-luvun loppupuolen musiikkitieteellisessä kirjallisuudessa pentatoniikan käsitettä käytettiin lukuisissa teoksissa. Suomalaisessa tutkimuskirjallisuudessa esiintyvien viitteiden mukaan merkittävimmät tutkijat tässä suhteessa olivat Hermann L. F. Helmholz (1954; alkup. 1877) ja Wallaschek (1893). Helmholz keskittyy kirjassaan säveltasojen mittauksiin ja siihen liittyvään teoreettiseen pohdintaan. Hän esittelee kuusi pentatonista asteikkoa ja antaa jokaiselle nuotinnetun esimerkin. Asteikot, jotka määritellään sen mukaan, mitkä diatonisen asteikon sävelet niistä puuttuvat, ovat seuraavat (Helmholz 1954: 258-262):

1. Pentatoninen asteikko (c-d- -f-g-a- -[c]) (Puuttuvat sävelet: 3. ja 7.)

2. Pentatoninen asteikko (c- -es-f-g- -b-[c]) (Puuttuvat sävelet: 2. ja 6.)

3. Pentatoninen asteikko (c-d- -f-g- -b-[c]) (Puuttuvat sävelet: 3. ja 6.)

4. Pentatoninen asteikko (c-d-e- -g-a- -[c]) (Puuttuvat sävelet: 4. ja 7.)

5. Pentatoninen asteikko (c- -es-f- -as-b-[c]) (Puuttuvat sävelet: 2. ja 5.)

6. Pentatoninen asteikko (c- -es-f-g-a- -[c]) (Puuttuvat sävelet: 2. ja 7.)

Helmholz pitää pentatoniikkaa tunnusomaisena musiikin varhaisvaiheille ja sille, että diatoniikka on kehittynyt pentatoniikasta. Wallaschek (1970: 153-154) huomauttaa kuitenkin, että Helmholzin arviot diatonisen säveljärjestelmän alusta perustuivat sen ajan puutteellisiin lähteisiin, ja että hänen kirjoittaessaan ei ollut vielä löydetty esimerkiksi Egyptin 2000 eaa. peräisin olevia huiluja, joissa oli diatoninen sävelikkö. Ilmiönä diatoniikka oli siten paljon varhaisempaa kuin siihen asti oli kuviteltu. Tarkatkaan mittaukset eivät antaneet lopullista vastausta musiikin alkuperäongelmiin:

Meidän diatonisen asteikomme säveliä (tai säveliköiden osia) on tavattu kivikauden instrumenteissa. Meillä ei ole syytä olettaa, että pentatonisten asteikkojen periodi olisi välttämättä edeltänyt heptatonisten asteikkojen aikakautta - - [K]aikkien näiden tosiseikkojen johdosta meidän täytyy hylätä teoria, jonka mukaan pentatoniset asteikot edelsivät nykyistä diatonisten sävelikköjen periodia. (Wallaschek 1970: 152, 155.)

1800-luvun lopulla ja 1900-luvun alussa lukuisat musiikin tutkimuksen pioneerit pohtivat pentatoniikkaan liittyviä kysymyksiä. Esimerkiksi saksalainen Frans Boas (1888: 240-258) kuvailee The Central Eskimo -teoksessaan pentatonisia asteikkoja, vaikkei itse pentatoniikka-termiä käytäkään. Myös Alexander J. Ellis (1885) kehitti eri kulttuureissa tavattavien säveljärjestelmien tutkimusta. 
Vuoden 1905 jälkeen Berliinin koulukunnan tieteenala tunnetaan nimellä vergleichende Musikwissenschaft eli vertaileva musiikkitiede, ja sen vaikutus laajeni Saksasta muualle Eurooppaan ja Pohjois-Amerikkaan. Ulkoeurooppalaisten musiikkien tutkimuksessa vertaileva musiikkitiede muodosti keskeisen metodologisen viitekehyksen aina 1950-luvun amerikkalaisen etnomusikologian syntyyn saakka. (Ks. Pekkilä 1984: 138-141.)

Muita 1800- ja 1900-lukujen vaihteen tutkimuskirjallisuuden pentatoniikkaan liittyviä tutkimushaaroja ovat Pohjois-Amerikan alkuperäiskansojen musiikkien tutkimus sekä skotlantilaisiin ja irlantilaisiin kansansävelmiin liittyvä tutkimus (Ellingson 1992: 116-121; Powers 1980: 419-420). Toistaiseksi on epäselvää, kuinka laajasti suomalaisilla tutkijoilla oli käytettävissään tätä kirjallisuutta.

Matti Huttusen (1993: 81-82) mukaan Suomessa vaikutti 1800-luvun jälkipuoliskolla kaksi näkemystä: fétisiläinen ja riemannilainen. Fétis (1869-76) edusti näkemystä, jonka mukaan maailmassa on olemassa useita erilaisia ja rinnakkaisia säveljärjestelmiä. Fétisin mukaan näyttää siltä, että ensimmäisillä musiikillisen kehityksen asteilla useat kansat välttivät sävelaskelta pienempien intervallien käyttöä. Siksi käyttöön muodostui asteikkoja, joissa vaihtelivat sävelaskeleen ja puolentoista sävelaskeleen intervallit. Fétisin kokoamien esimerkkien perusteella tällaisia asteikkoja tavataan kiinalaisessa musiikissa, mutta myös "mongolisen rodun" muiden haarojen, kuten Jaavan ja Sumatran malajien, Hudson Bayn asukkaiden, Uuden Guinean papualaisten, Uuden Kaledonian asukkaiden ja Fullahin mustan väestön keskuudessa. Suomessa fétisiläistä näkemystä edusti muun muassa Heikki Klemetti (1922).

Alexander Rehding on analysoinut Hugo Riemannin ajattelun lähtökohtia. Keskeinen riemannilainen periaate on se, että kaikki musiikki voidaan palauttaa duuri-molli-tonaalisuuteen. Musiikinhistorian keskeisenä olemuksena on siten yhden perusidean eli duuri-molli-tonaalisuuden vähittäinen täydellistyminen. Pentatoniikka käsitettiin riemannilaisuudessa osaksi universaalia säveljärjestelmää, jonka perustana ajateltiin olevan duuri-molli-tonaalisuus. Tässä ajattelussa pentatoniikka ei ollut olemassa itsenäisenä säveljärjestelmänä vaan se oli epätäydellinen esitonaliteetti. Pentatoniikka edusti eräänlaista diatoniikan puolisävelaskeleetonta perustaa, sillä kaikille maailman kansoille ei kuitenkaan ollut valjennut täydellisen diatonisen asteikon mahdollisuudet kokonaisuudessaan (Rehding 2003: 125). Riemannin merkittävin pentatoniikka-aiheinen tutkielma on vuonna 1916 ilmestynyt Folkloristische Tonalitätsstudien. Myös Riemann tuo esiin ne osana antiikin Kreikan ja Japanin musiikeissa sekä skotlantilaisessa ja irlantilaisessa musiikissa. (Rehding 2003: 170). 
Suomalaisen musiikintutkimuksen varhaisvaiheiden kannalta tämä kirjoitus on kuitenkin myöhäinen, sillä 1910-luvulla pentatoniikkaa käsiteltiin jo sangen yleisesti suomalaisessa musiikinteoreettisessa kirjallisuudessa.

\section{IImari Krohnin artikkeli "Kansansävelmien alkuperästä" (1901)}

Suomessa riemannilaista ajattelua edusti selkeimmin Ilmari Krohn ja hänen oppilaansa Armas Launis ja myöhemmin myös A. O. Väisänen. Vuosisadan vaihteen suomalaisen kansanmusiikin tutkimukselliset lähtökohdat tulevat hyvin esiin Ilmari Krohnin vuonna 1901 julkaisemassa artikkelissa "Kansansävelmien alkuperästä". Krohn käy läpi näkemyksensä eri aikojen ja kulttuurialueiden musiikillisista ominaispiirteistä sekä perustelee näiden tutkimisen tarpeellisuutta sekä tieteen että taiteen kannalta:

Kysymys kansansävelmäin alkuperästä on siis varsin tärkeä sekä tieteellisessä että taiteellisessa suhteessa. Kaksi eri mielipidettä on siitä kysymyksestä ilmennyt; aineksien ääretön laajuus ja verraten äskeinen kerääminen on estänyt tähän asti ratkaisevaa vastausta löytymästä. (Krohn 1901: 549.)

Krohn tuo esiin ajatuksen kaiken musiikin yhteisestä alkuperästä, kaikkea musiikkia koskevista luonnonlakimaisista periaatteista. Krohnin mukaan eri kansojen sävelmissä havaitaan kyllä ensi kuulemalta selviä kansallisia piirteitä, joista kuitenkaan tarkemmassa musiikkianalyysissä (rytmit, intervallit, sävelkäänteet) "ei tahdo jäädä käsiin tuntuvata juuri mitään". Samoin voimakkaasti persoonallisten taidemusiikin säveltäjienkin sävellyksiä vertailtaessa voidaan havaita, että "matemaattiselta määrittelyltä [ero] haihtuu ikään kuin usvaksi".

Luopua tosin on täytymys kansansävelmäin kansallisen syntyperän oletuksesta. - - [K]ansallisen värityksen tuoksu ei sisällykkään pelkkään muotoon, joka saattaa hyvinkin olla muualta lainattu tai yhteistä tavaraa muitten kansojen kanssa, vaan se piilee ennen kaikkea jokaisen kansan kielessä ja siitä johtuvassa laulusävelmien deklamatsionissa eli kielenmukaisessa taipumisessa. Siinä kyllä joudutaan alalle, jossa sävelten hento maailma pujahtaa määrittelijän käsistä pois tulenhengen lailla, mutta jossa sydämen kieltä on kuultavissa jokaiselle, kellä on sydämessä sille vastakaikua. (Krohn 1901: 557-558.) 
Krohn ryhmittelee musiikin ensiksi eurooppalaisten kansojen diatoniseksi, toiseksi eteläaasialaisten kromaattiseksi musiikiksi, jota tavataan jopa 1/3- tai 1/4-intervalleissa liikkuvana. Kolmantena ryhmänä on "raakalaiskansojen" musiikki, jolle Krohn ei kuitenkaan tarjoa muuta määritystä kuin sille ominaisen muodon puutteen. Euroopan kansojen musiikin Krohn jakaa kahteen ryhmään: eeppiseen ja lyyriseen. Niiden määräävimpänä erona on "muinaisen musiikin" kirkkosävellajien ja $d u r$-sävellajien vastakohtaisuus. Dur-sävellaji korostuu erityisesti saksalaisen kansanhengen ja protestanttisen kristillisyyden leviämisen yhteydessä. Tästä musiikista kehittyi uudemman ajan soinnullisuus ja dur-sävellajit eli duuri-molli-tonaalisuus. Kaiken musiikin yhteinen perusta, dur-sävellaji, on kuitenkin historiallisessa katsauksessa haasteellinen, sillä Krohn ei tahdo löytää sille vastineita muinaisesta maailmasta. Hän kuvaakin lähinnä kirkkosävellajien edustavuutta vanhemmassa yksiäänisessä musiikissa. (Krohn 1901: 550-552.)

Eepillisiksi Krohn nimittää "kaikkia sellaisia sävelmiä, jotka muodostuvat yhden tai kahden meloodisen lauselman (fraasin) alinomaisesta kertaamisesta". Näiden joukkoon kuuluvat kalevalaiset kertomarunot, paimenhuhuilut, kehtolaulut, työtä säestävät laulelmat, kaupustelijain huudot ja jopa useat jumalanpalveluksessa käytetyt messusävelmät. "Raakalaiskansojen" musiikki on melkein yksinomaan eeppistä eli Krohnin sanojen mukaan "seurausta saman eepillisen rakenteen alituisesta kertaamisesta". Siksi niitä on pidettävä epäilemättä kansanlaulun vanhimpana muotona, joiden alkuperänä voisi pitää tavallisen puheen luonnollista kohoutumista ja laskemista. Musiikin alkusynnyn hetki liittyy hänen mukaan julkisiin juhlallisiin rukoustilanteisiin. (Krohn 1901: 551-552.)

Krohnille"raakalaiskansojen" musiikin keskeiseksi ominaisuudeksi nousee muodon puute, siis kehittymättömyys sivistyskansojen kehittyneisyyden vastakohtana. On selvää, että vuoden 1901 tilanteessa Krohnin tiedot erilaisista musiikkikulttuureista olivat hyvin puutteelliset, vaikka hän kertoo lähteinään olleen lukuisia - nimeltä kuitenkaan mainitsematta - oman aikansa kansansävelmäkokoelmia.

Niin sanottuja primitiivisiä musiikkikulttuureja käsittelevien 1800-luvun kirjoitusten yhteydessä oli ollut jo pitkään käytäntönä käsitellä pentatoniikkaa osana tällaisten kulttuurien säveljärjestelmää. Krohnin artikkelin perusteella pentatoniikka ei näytä olleen käsitteenä käytössä suomalaisessa kansanmusiikintutkimuksessa vielä vuosisadan vaihteessa.

Sen sijaan Krohnin artikkelissa on esillä 1900-luvun alun kirjoituksille tyypillinen tapa määritellä kehitysopillisesti alemmalla kehitysvaiheella olevien "raakalaiskan- 
sojen" kulttuuria negatiivisten käsitteiden kautta. Havaitut tai oletetut kulttuuripiirteet olivat kehittyneen kulttuurin vastakohtia. Kulttuurikansoilla kehittyneen kulttuurin tunnusmerkkinä oli kehittynyt muoto. Alempien kansojen tyypillinen piirre oli sen sijaan vain muodon puute. (Vrt. Jouste 2001a.)

\section{Pentatoniikka Armas Launiksen kirjoituksissa 1904-1909}

Suomalaiseen kansanmusiikintutkimukseen pentatoniikka-käsite ilmestyy Armas Launiksen pohjois- ja inarinsaamelaisiin musiikkiperinteisiin liittyvän työn mukana. Saamelaisten musiikkikulttuurien tutkimus toi esille suomalaisia tutkijoita lähellä olevan musiikkiperinteen, jonka Launis määritteli pentatoniseksi. Suomalaisen Kirjallisuuden Seuran ja Helsingin Yliopiston stipendiaattina Launis teki kaksi keräysmatkaa Lappiin vuosien 1904 ja 1905 kesinä. (Launis 1986; Järvinen 2004; Jouste 2004.)

Launiksen analyyttisen mielenkiinnon kohdetta voi seurata hänen lukuisien artikkeliensa (1904; 1905; 1907a-c; 1909) sekä laajan sävelmäkokoelman Lappische Juoigos-Melodien (1908) avulla. Vuosien 1904 ja 1905 matkakuvauksissa Launis käsittelee laajasti keräämäänsä sävelaineistoa. Joikusävelmiä ja joikaamista kuvaillaan yleisesti sekä kulttuurisena toimintana että musiikkianalyyttisesti. Launiksen työ muodostaa kokonaisuutena erittäin laajan ja kattavan kuvauksen pohjoissaamelaisesta musiikkikulttuurista.

Ei ole tiedossa, milloin Launis hahmotteli pentatonisen teoriansa. Hänen laajoissa matkapäiväkirjoissaan ei ole mainintaa, jossa joikusävelmistöä kuvailtaisiin pentatonisena (ks. Launis 2004). Vuosien 1904 ja 1905 matkaraporteissa ei ole musiikkianalyyttistä pohdintaa. Ensimmäisen kerran pentatoniikka-termi esiintyy Launiksen kirjoituksissa vuonna 1907 "Lappalaisten joikusävelmät I-III" artikkelisarjassa, jonka viimeisessä osassa Launis kuvailee keräämäänsä joikusävelmistöä musiikkianalyyttisesti. Launista (1907c: 72) kiinnostavat erityisesti sävelmien rytmiikka ja muotorakenne. Joikujen melodista puolta hän pitää toisarvoisena edellä mainittuihin verrattuna:

Musikaalisista keinovaroista, joita lappalaisella on joikusävelmää laatiessa käytettävänään, on rytmiikillä merkitsevin sija, melodiikilla vasta toisarvoinen asema. Asian ymmärtää helposti, kun tietää, miten vähän kehittyneitä lappalaiset ovat laulutaidossa. Enimmäkseen he joko kirkuvat tai ynisevät nenäänsä. 
Kaunis ja omintakeisia viehättäviä meloodisia käänteitä sisältävä melodiikki ei näin ollen voi kehittyä, se kun ei kuitenkaan saattaisi niin alkuperäisellä tavalla esitettynä vaikuttaa. (Launis 1907c: 72.)

Launiksen ajatus rytmin merkittävyydestä on tuttu myös Wallaschekilta (1891: 375), jonka mukaan "[1]aajasti tunnettu tosiasia, joka perustuu matkailijoiden ja tutkijoiden havaintoihin, on se, että primitiivisen musiikin ainoa olennainen piirre on rytmi, melodian liittyessä sattumanvaraisuuteen."

Launis (1907c: 75) jatkaa seuraavasti:

Joikusävelmäin melodiikasta ei ole paljon sanottavaa. Meloodinen ulottuvuus on yleensä pieni ja koska useat sävelmät liikkuvat etupäässä luonnonharmoniaan kuuluvilla sävelillä, eivät edes kaikki ulottuvuusrajojen sisäpuolella olevat sävelet tule käyttöön. Enin osa sävelmiä liikkuu n.k. pentatoonisella äänialalla, viisi-askelolla, jossa ei puoli-ääni-askeleita tavata (esim. c-d-f-g-a). Koska viisiaskelo on tavallinen raakalaiskansojen sävelmissä, joihin kehittyneemmän musiikin tuotteet eivät ole vielä päässeet vaikuttamaan, on tämä selvänä todistuksena siitä, että lappalaiset ovat ainakin jossain määrin säilyneet suojassa ulkoapäin tulevilta vaikutteilta.

Vaikka Launiksen kirjoitukset ovat moniin muihin aikalaiskirjoituksiin nähden saamelaiskulttuuria ymmärtävästi käsitteleviä, on selvää, että hänen oli otettava tiedeyhteisön sisällä julkaistuissa kirjoituksissa kantaa oman aikansa keskeisiin kulttuuriteoreettisiin näkemyksiin. Tärkein kulttuurintutkimuksen viitekehys oli tuolloin universaali evolutionistinen malli, johon kuuluivat esimerkiksi sekä Krohnin että Launiksen teksteissä esiintyvät ajatukset "raakalaiskansoista" ja niiden kulttuurin - eli myös musiikin - kehittymättömyydestä.

Launiksen saamelaisen musiikkiperinteen työn merkittävin yksittäinen teos on vuonna 1908 ilmestynyt Lappische Juoigos-Melodien -kokoelma. Kirjan laajassa esipuheessa Launis keskittyykin ensisijaisesti joikujen rytmisiin piirteisiin, säerakenteisiin sekä sävelmien ambitusten käsittelyyn. Sävelmien tonaalisen puolen käsittelyyn Launis käyttää vain kaksi sivua.

Merkillepantavin erikoispiirre on melodiikan pitäytyminen pentatonisessa sävelikössä (Tonleiter). Tämä pätee miltei 3/4:aan kaikista sävelmistä. Kuitenkin suuressa osassa näistä on ei-täydellisiä viisiasteisia sävelikköjä ja melodiat liikkuvat näin vain muutamilla tähän asteikkoon kuuluvilla sävelillä. Näiden ohella löytyy joukko duurisävelmiä, joiden säveliköt sisältävät vain yhden puoliaskelen - johtosävelen tai kvartin. (Launis 1908: XXXI-XXXII.) 
Vaikka Launiksen Lappische Juoigos-Melodien -kokoelmassa joikusävelmien melodia-analyysi jää rytmiikan varjoon, hän toteaa kuitenkin, että aikoo tulevaisuudessa käsitellä asiaa erillisessä tutkimuksessa. Joikusävelmien tonaalisuutta koskevat ajatuksensa Launis esitteli vuonna 1909 Wienissä järjestetyssä Haydnzen Tonfeier III. Kongress der Internationalen Musikgesellschaft -kongressissa pitämässään esitelmässä. Esitelmä julkaistiin kyseisen kongressin julkaisussa (Launis 1909). Artikkelista on olemassa myös painettua versiota laajempi käsikirjoitusversio, jota säilytetään Helsingin yliopiston kirjaston kokoelmissa (ks. myös Launis 2008 ja Niemi 2008 tässä vuosikirjassa).

Mitään kattavaa esitystä ei julkaisussa ole sävelmien ehkä kiinnostavimmasta puolesta, niiden melodiikasta, koska se on varattu erillistä tutkimusta varten, johon olenkin jo ryhtynyt. Näistä sävelmien melodisista piirteistä haluaisin käsitellä tässä joitakin kohtia, jotka ovat tulleet minulle selviksi sävelmäkokoelman tutkimuksen yhteydessä.

Kokoelman 854 melodiasta huomattavan suuri osa, 567 (2/3) liikkuu pääasiassa kokoaskelista koostuvissa pentatonisissa skaaloissa. Muut melodiat käyttävät useimmiten diatonisten sävelikköjen kuutta säveltä, poikkeuksena vain 7 täysimittaista seitsensävelikköä käyttävät melodiat. Niistä jotkut harvat on tallennettu syvällä Lapin sydämessä Koutokeinossa. Yhdellä kansalla on siis näin rikas pentatoninen sävelikkövalikoima ja tässä on hyvä tilaisuus tutkia niitä ja niitä hallitsevia lakeja, ainakin tämän kokoelman nojalla.

Koska olen havainnut pentatoniikan eri muodot tonaalisiksi, olen erityisellä johtamistavalla, josta on tarkemmin puhetta LJM:ssä [Lappische Juoigos-Melodien], erottanut neljä pääasiassa kokoaskelliikkeeseen perustuvaa pentatonista asteikkoa, kaksi duurissa ja kaksi mollissa, jotka kaikki esiintyvät kokoelmassa. (Launis 2008.)

Joikusävelmien melodiikka onkin tässä vaiheessa noussut Launikselle kaikkein kiinnostavimmaksi puoleksi joikusävelmien analyysissa rytmin ja muotorakenteen sijaan. Tämän muutoksen syynä voidaan olettaa olleen se, että Launis oli aloittanut pentatonisen säveljärjestelmän mallin soveltamisen keräämäänsä joikusävelmistöön. Juuri duuri-molli-tonaalinen säveljärjestelmän malli, jossa yksittäisille sävelille voitiin hahmotella sävelhierarkiset funktiot, mahdollisti myös joikusävelmien vähäsävelisten asteikkorakennelmien tulkitsemisen.

Malli, jota Launis soveltaa on tuttu jo Helmholzilta (1877; alkup. 1854). Pentatoniset asteikot tulkitaan diatonisiksi asteikoiksi, joista puuttuu sävelasteita. Pentatoniikkalajin määrittely tapahtuu kolmen piirteen perusteella. Ensiksi tarkastellaan sitä, onko kyseessä anhemitoninen vai hemitoninen pentatoniikka. Toiseksi määritellään asteikon terssin laatu ja jaetaan asteikot duuri- ja molliasteikkoihin. Kolmanneksi 
jaetaan kumpikin ryhmä vielä alalajeihin sen mukaan mitkä sävelasteet puuttuvat kun niitä verrataan diatoniseen asteikkoon. Launis (1909) löysi keräämästään pohjoissaamelaisesta joikusävelmistöstä seuraavat pentatoniset pääluokat:

1. Pentatoninen duuriasteikko (Puuttuvat sävelet: 4. ja 7.)

2. Pentatoninen duuriasteikko (Puuttuvat sävelet: 3. ja 7.)

1. Pentatoninen molliasteikko (Puuttuvat sävelet: 2. ja 6.)

2. Pentatoninen molliasteikko (Puuttuvat sävelet: 3. ja 6.)

Launiksen pentatonisessa mallissa eri pentatoniikan muotoihin määritellään vielä alalajeiksi se, minkälainen on melodian ambituksen vaikutus asteikon tonaalisiin funktioihin sekä mitä tonaalisia tukisäveliä saadaan näin asteikkoon.

Launiksen mallin osana on myös ajatus siitä, että pentatoniikassa ei tarvitse olla edustettuna täydellinen viisisävelinen asteikko. Sävelfunktioiden ja niiden kautta määriteltyjen tonaalisten tukipisteiden kautta sävelmät, joissa on vähemmän kuin viisi sävelastetta, voidaan tulkita kuuluvan aina tiettyyn pentatoniikan lajiin (vrt. myös Laitinen 2003: 294-297). Launis jakaakin aineistonsa 1. pentatonisen duuriasteikon luokan vielä 22:een alatyyppiin juuri 4 . ja 7 . asteen lisäksi puuttuvien sävelten mukaan.

Launiksen tutkimustyö on eräänlainen Suomen musiikintutkimuksessa ilmenevä alkuhetki sille, että pentatoniikka yhdistetään kehitysoppiin. Oli löydetty suomalaisen perinteenkeräyksen ja tutkimuksen tuloksena kulttuuri, joka ajan yleisten näkemysten mukaan edusti varhaista kehitystasoa ja jonka musiikista pystyttiin teoreettisesti osoittamaan myös kulttuurin varhainen kehitysvaihe. Saamelaisten ja muidenkin primitiivisiksi määriteltyjen kansojen kulttuurin keräys ja tutkimus liittyi haluun selvittää 1900-luvun alun tutkijoiden oman kulttuurin oletettuja varhaisvaiheita. Launiksen mukaan joikusävelmissä oli kuultavissa "ääniä menneiltä vuosisadoilta, kansakuntain lapsuusvuosilta" (Launis 1907c: 76).

Arvoitukseksi jää kuitenkin kysymys siitä, miksi Launis ei kuitenkaan julkaissut joikusävelmien melodisista piirteistä tekemänsä tutkimuksen tuloksia vuoden 1909 konferenssiesitelmän ja siitä tiivistelmänä julkaistun artikkelin ohella, vaikka hän viittaa käynnissä olleeseen laajempaan selvitykseen. Vuoden 1909 artikkeli jäikin Launiksen viimeiseksi joikusävelmistöä käsitteleväksi kirjoitukseksi. 


\section{IImari Krohnin Säveloppi (1916)}

Ilmari Krohn liitti pentatoniikka-aiheen musiikinteoreettisen käsittelyn vuonna 1916 ilmestyneeseen Säveloppi-teokseensa. Krohn tulkitsee pentatoniikan olemuksen - kuten kaiken musiikin - duuri-molli-tonaaliseksi. Hän perustelee näkemystään seuraavasti:

Vasta uusimman ajan vertaileva kansansävelmätutkimus on kiinnittänyt teoreetikkojen huomion jälleen 1-äänisen melodiikan tonaalisiin suhteisiin (Tiersot, Hornbostel, Thuren, Norlind, Launis y. m.). Niiden tutkiminen onkin välttämätön tuloksien saavuttamiseksi sävelmäin vertaamisessa. Tosin useat tutkijat vastustavat uuden ajan synnyttämän tonaalisuuskäsitteen sovelluttamista kaukais- ja luonnonkansojen 1-äänisiin säveltuotteisiin ja tyytyvät sen vuoksi sävelkulkujen akustisiin mittauksiin ja ylimalkaiseen melodisten piirteiden erittelemiseen. Mutta selvää on, ettei siten saavuteta yhtenäistä vertailun pohjaa. Sitä paitsi on itse olettamuskin erehdyttävä, että muka tonaalisuuskäsitteellä ei olisi täyttä vastinettansa 1-äänisissä sävelmissä. (Krohn 1916: 9; alkup. korostus.)

Krohnin mukaan pentatonisia asteikkoja on useita eri lajeja sekä duurissa että mollissa. Krohn tulkitsi pentatoniikan laadun sen mukaan, mitkä sävelet tarvitaan täydennykseksi, asteikot muuttuisivat 7-sävelisiksi diatonisiksi duuri- tai molliasteikoiksi. Tavallisin duurimuoto on sellainen, jonka duurimuodosta puuttuvat 4. ja 7. aste. Mollimuodoista yleisimmästä puuttuvat puolestaan 2. ja 6. aste. Näitä vastaavat Helmholzin esityksen 4. asteikko (c-d-e- -g-a- -[c]) ja 2. asteikko (c- -es-f-g- -b-[c]). Krohn kutsuu näitä muotoja varsinaispentatoniikaksi. Krohnin (1916: 268) mukaan

on varsinaispentatoniikka erinomaisen tärkeä tonaaliselta merkitykseltään. Siihen perustuu koko Itä-Aasian musiikki. Myös luonnonkansojen sävelmissä, etenkin Aasiassa, Amerikassa ja Australiassa, on sillä huomattava sija resitatiivisten tyyppien ohella. Sitä paitsi se tuntuu perusrunkona keskiajan gregoriaanisessa melodiikassa sekä kelttiläisessä ja skandinavialaisessa kansanlaulusävelmistössä. - -

[V]arsinaiselle pentatoniikalle - - on ominaista puoliaskelten puuttuminen. Siitä johtuu sävelaiheitten sävyyn jotain objektiivista, luonnonomaista, vastoin täysin diatonisen melodiikan selvää yksilöllisyyttä. Kun kokoaskelet ovat pienimpinä käytettävinä intervalleina, liikkuu sävelkulku mielellään laajoissa hypyissä, riittävän vastakohdan aikaansaamiseksi. - -

Varmasti voidaan myös päättää, että pentatoniikka edustaa ihmiskunnan varhaisimpien sivistyskausien saavutusta musiikkityylin alalla. Pentatonisesta 
melodiikasta on sitten diatoninen luonnollisesti sukeutunut, arvattavasti alkeellisten resitatiivisten ainesten avulla. Tämän kautta osouttautuu myös oikeutetuksi se järjestelmä, jota noudattaen olemme tähän asti oppijaksossa sävel säveleltä kehitelleet käytettäväämme sävelaineista.

Krohnin (1916: 265-283) pentatoniikka-esitys noudattelee siis pitkälti jo Helmholzilta ja myös Launikselta tuttua muotoa. Krohn viittaakin juuri Launiksen "Die Pentatonik in den Melodien der Lappen" -artikkeliin. Krohn (1916: 451-453, 462) käsittelee Sävelopissaan edellisen lisäksi vielä kiinalaisia ja japanilaisia pentatonisia sävellajeja erillisissä luvuissa. Lisäksi hänellä on laaja pentatonisten musiikkiesimerkkien luettelo, jossa on taidemusiikkirepertuaarista poimittujen melodioiden ohella runsaasti ei-länsimaisten kansojen musiikkia.

\section{Luonnonkansojen musiikki}

Launiksen ohella vuodelta 1907 löytyy toinenkin pentatoniikka-termin maininta. Kyseessä on Aksel Törnuddin teos Musiikinhistoria pääpiirteissään seminaareja ja musiikinharrastajia varten. Huttusen mukaan (1993: 59-60) tämä musiikinhistorian yleisesitys oli yksi 1900-luvun alun Suomen luetuimpia musiikkikirjoja. Siinä käsiteltiin ensimmäisen kerran suomalaisessa musiikinhistorian yleisesityksessä luonnonkan-
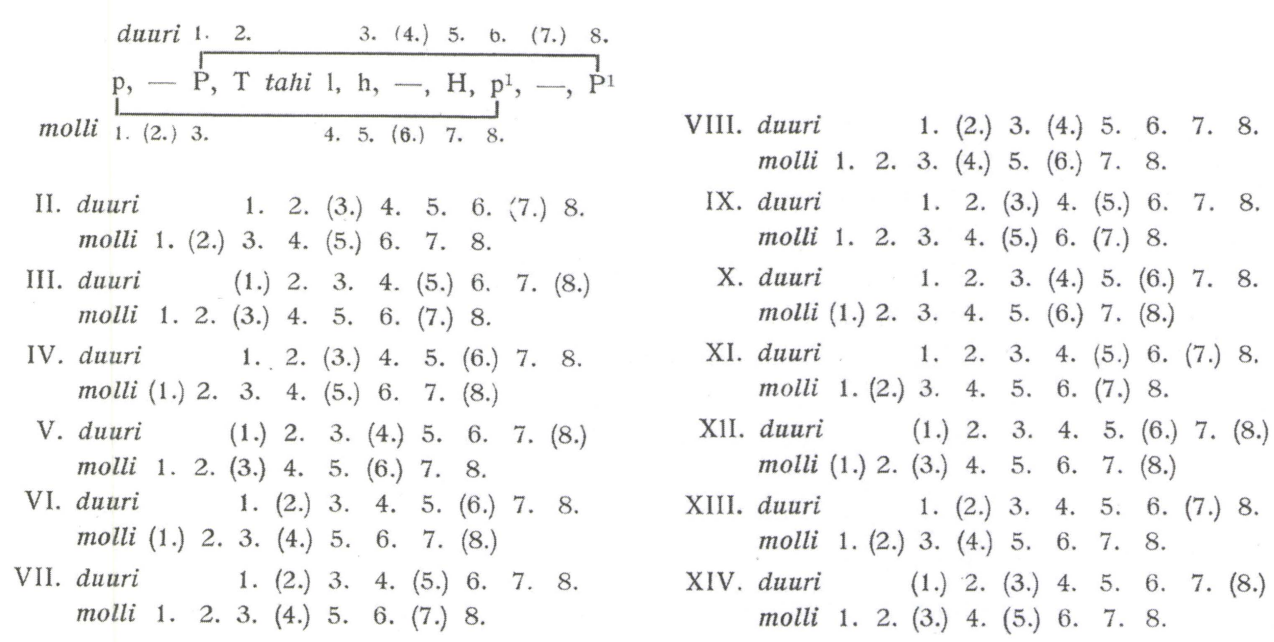

Taulukko 1. Krohnin (1916: 266-267) pentatoninen järjestelmä. 
sojen musiikkia länsimaisen musiikin rinnalla. Pentatoniikka liitettiin luonnonkansojen musiikkikulttuureihin:

Luonnonkansojen säveljärjestelmästä ei ole vielä saatu aivan täydellistä selkoa. Niin paljo lienee kuitenkin varmaa, että ainakin useimmilla on 5-sävelinen skaala. Niin on vieläkin monilla luonnonkansoilla Aasiassa, niin oli luultavasti alkuaan myös vanhoilla kreikkalaisilla, vanhoilla suomalaisilla y.m. (Törnudd 1907: 6; siteerannut Huttunen 1993: 60.)

On selvää, että tiedon vähyys luonnonkansojen musiikeista oli vielä 1900-luvun alkuvuosina sangen vähäistä, kuten Ilmari Krohnkin asiaa kuvasi. Pentatoniikkatermin käyttö ei kuitenkaan ollut itsestään selvää suomalaisessa tutkimuskirjallisuudessa edes luonnonkansojen musiikkien kuvailun yhteydessä. Käsite ei esimerkiksi esiinny kertaakaan Väinö Salmisen (1906; 1907a; 1907b) pohjoissaamelaista joikua käsittelevissä artikkeleissa.

Tultaessa 1910-luvulle tieto maailman musiikkikulttuureista lisääntyi Suomessa. Huomattavia olivat muun muassa jatkuvat kontaktit saksalaiseen ja angloamerikkalaiseen musiikintutkimukseen esimerkiksi musiikintutkimuksen kansainvälisissä kongresseissa Baselissa 1906, Wienissä 1909 ja Lontoossa 1911, joista kaikissa oli läsnä Ilmari Krohn ja jälkimmäisissä myös Armas Launis sekä Otto Andersson (Crowdery ym. 2004: 8-12). Tiedon määrän kasvaessa muuttui myös tutkimuksen näkökulma. Krohn (1911: 499; alkup. korostus) kuvaa muutosta seuraavasti:

\begin{abstract}
Alkuaan kohdistui kansanlaulun tutkimus kansallisten erikoispiirteiden selvillesaamiseen; myöhempi suunta on kiinnittänyt huomionsa päinvastoin niihin yllättäviin yhteispiirteisiin, jotka ovat tavattavina mitä kaukaisimpien ja erilaisimpien kansojen sävelmistöissä sekä saman kansan piirissä havaittaviin eri aikakausien taidetyylejä heijastaviin kerrostumiin. Yhä varmemmaksi käy se käsityskanta, jonka mukaan kansansävelmäin tyyliainekset ovat jätteitä entisaikoina ylempien kansankerrosten käyttämistä taidemusiikeista. (Krohn 1911: 499.)
\end{abstract}

"Erikoispiirteillä" Krohn viittaa ilmeisesti "kansansävelmäin kansalliseen syntyperään" liittyviin kysymyksiin, joita hän pohti vuoden 1901 artikkelissaan. "Yhteispiirteet" sen sijaan ovat kansallisuusrajat ylittäviä ja kaikkiin musiikkeihin sovellettavia piirteitä. Näistä ensimmäisenä mainitaankin pentatoniikka, joka on artikkelin seuraavan luvun otsikko: 
1. Pentatoniikka. Pentatonisiksi nimitetään sellaisia sävelkulkuja, jotka muodostuvat 5-sävelikön (esim. pianon ja harmonin mustien koskettimien edustaman) asteikon mukaisesti. Niitä tavataan miltei kaikkialla pohjoisen Aasian ja Amerikan kansoilla; sitä paitsi on pentatoniikalla valta-asema kiinalaisten ja heidän naapurikansojensa musiikeissa, jonka vuoksi ollaan taipuvaisia olettamaan sen edustavan ihmiskunnan vanhinta kerrostumaa. Myös Volgan varsien suomensukuiset kansat käyttävät pentatoniikkaa sävelmissään, samoin Brittein saarten kelttiläiset suuressa määrässä. Lähimmässä naapurustossamme laulavat lappalaiset joikunsa pentatonisin sävelin. Myös omassa kansanlaulussamme tätä ilmiötä tavataan aivan tilapäisesti ja nähtävästi sattumoisin. Ainoastaan Vienan Karjalan karjankutsuntasävelmissä ja tuohitorvensoitoissa esiintyy pentatoniikka selvänä tyyliä määräävänä aineksena (esim. A. O. Väisänen: Itä-Karjalan runous ja musiikki). (Krohn 1911: 500.)

Vuoden 1901 artikkeliin verrattuna Krohnin näkemys musiikin oletetuista varhaisvaiheista on muuttunut huomattavasti myös siinä, että pentatoniikka muodostui keskeiseksi tekijäksi lukuisten ulkoeurooppalaisten kansojen musiikkikulttuurien kuvauksissa. Raakalaiskansan sijaan käyttöön on tullut luonnonkansa. Krohnin "Luonnonkansojen musiikki" -artikkeli Tietosanakirjassa vuonna 1913 on seuraavanlainen:

Luonnonkansojen musiikki on tullut viime aikoina yhä enenevän mielenkiinnon esineeksi. Toisaalta arvellaan sen tutkimisen avulla päästävän selville musiikin alkuperästä, toisaalta taas toivotaan siten saatavan selkoa vanhan ajan sivistyskansojen musiikin laadusta, edellyttäen että senaikaisesta musiikista on rippeitä säilynyt luonnonkansoilla. Nykyään kerätään fonografin avulla l:jen sävelmiä kaikkialla, joten tulokset ovat luotettavammat kuin yksityisten matkailijain satunnaiset ja hajanaiset muistiinpanot. - - Vertaileva tutkimus on osoittanut 1. m:ssa olevan yhteisiä piirteitä yli koko maapallon. Etenkin herättää huomiota pentatonisten sävelmien runsaus sekä melodiikan yleisten tonaalisten perusteiden yhtäpitävyys. (Krohn 1913: 1242.)

Krohn pohtii artikkelissaan vielä moniäänisyyden syntyä, joka näyttää olevan hänen keskeinen kiinnostuksen kohteensa. Lähdekirjallisuutena Krohn mainitsee Wallaschekin Primitive Music -teoksen ja erityisesti sen saksannoksen vuodelta 1903, E. M. von Hornbostelin vuoden 1906 kongressiesitelmän sekä Launiksen Lappische Juoigos-Melodien -kokoelman.

Luonnonkansojen musiikki ja pentatoniikka esiintyvät myös Heikki Klemetin (1922) kaksiosaisessa teoksessa Musiikin historia. Siinä käsitellään ulkoeurooppalaisia musiikkikulttuureita kahdessa ensimmäisessä luvussa. Ensimmäisessä luvussa käydään läpi lukuisia näytteitä eri luonnonkansojen musiikeista, muun muassa 
Ceylonin saaren Wedda-kansalta, Tulimaan alkuperäisväestöltä, Vienan-Karjalasta, Melanesian Nissanin saarelta, papualaisilta, togoilta, bantuilta, Salomonin saarelta, saamelaisilta, tšeremisseiltä (Klemetti 1922: 1-12). Lähteet on kerätty kirjallisuudesta. Toisen luvun nimenä on "Kaukaismaiset sivistyskansat", joista käsitellään erikseen kiinalaiset, japanilaiset, intialaiset ja "arapit". Pentatoniikka on läsnä keskeisenä piirteenä.

Pentatonisiksi (=viisisävelisiksi) sanotaan sävelmiä, joiden sävelistö rajoittuu vain 5:een säveleeseen ynnä näiden oktaaveihin. Yleisen, nimityksen tavallisesti tarkoittama laji ei ollenkaan käytä puoliaskelisia intervalleja; sen asteikkokaava on $c d f g a$, alkusäveleeseen nähden eri muuntein. Näin rake[nne]tuille sävelmille ominaista on teeskentelemätön, luonnonraikas tunneilme.

Myös toisenlaisia viisisävelisiä sävelmiä tavataan, nykyaikaisia japanilaisia esim., joiden asteikkokaava on varsinaisesta pentatonisesta e fis a $h$ cis' johdettu puolisävelaskelinen $e f a h c^{\prime}$. Eroitukseksi varsinaisesta kokoaskelisesta sanotaankin tämmöistä seitsensävelisluonteista pentatoniikkia "johdetuksi". (Klemetti 1922: 3-4, alaviite.)

Ilmari Krohn (1935: 1199) määrittelee pentatoniikan Isossa Tietosanakirjassa seuraavasti:

Pentatoninen (< kreik.), mus., 5-sävelinen asteikko, vaihtelee laadultaan sen mukaan, mitkä 7-sävelisen duuri- t molliasteikon sävelistä on jätetty pois. Yleisimmin puuttuu duurin 4:s ja 7:s (= mollin 6:s ja 2:nen), harvemmin mollin 4:s ja 7:s aste. Kaikkia p:n melodiikan eri mahdollisuuksia tavataan lappalaisten joikusävelmissä. Luultavasti p. musiikki edustaa ikivanhaa säveltaiteellista kehityskautta. P:ia sävelmiä tavataan mm. Japanissa, Taka-Intiassa, useilla Pohjois-Aasian, Pohjois-Amerikan ja napaseutujen kansoilla, tšeremisseillä ja tšuvasseilla, unkarilaisilla sekä Brittein saarien kelttiläisillä. Skand. kansanmusiikissa ja gregoriaanisissa kirkkosävelmissä tuntuu p:ta pohjavirtausta. Oletetaan myös kreikk. "enharmonisten" asteikkojen olleen p:ia Pianolla syntyy p. asteikko, kun soitetaan pelkillä mustilla koskettimilla. (Krohn 1935: 1199.)

Krohnin näkemys on laajentunut käsittelemään pentatonisuutta osapuilleen siinä laajuudessa kuin se nykyisinkin tunnetaan vaikka joikusävelmät ovat edelleen viittauksissa ensimmäisinä. 


\section{Pentatoniikka-käsite osana musiikin varhaisvaiheiden pohdintaa}

Musiikkitieto-lehdessä julkaistiin vuonna 1935 kahden artikkelin kokonaisuus "Musiikin synty" ja "Musiikin synty II". Näissä A. O. Väisänen käsittelee neljää 1800-luvun lopun ja 1900-luvun alun musiikin syntyä pohtivaa teoriaa. Väisänen tiivistää mitä ilmeisimmin Suomessa 1800-luvun lopun ja 1900-luvun alkupuolen musiikin oletettujen varhaisvaiheiden ominaisuuksista käydyn keskustelun.

Väisänen (1935a: 126-127; 1935b: 138-139) aloittaa musiikin syntyä valottavien teorioiden käsittelyn Charles Darwinin ajatuksilla. Darwinin mukaan musiikin syntyvaiheet liittyvät sekä eläimillä että ihmisillä parinvalintaan ja kosiskeluun. Hän oli myös sitä mieltä, että ihminen käytti musiikiksi katsottavaa ilmaisutapaa ennen kuin hän oppi puhetaidon.

Väisänen esittää kritiikkinä Darwinia kohtaan sen, että eläinten ja ihmisten musiikilla on lukuisia eroavaisuuksia: muun muassa se, että luonnonkansoilta oli tuolloin löydetty verraten vähän lemmenlauluja ja sen sijaan runsaasti sota-, taika- ja uskonnollisia lauluja. Parinvalinta ja kosiskelu eivät ole kovin huomattavasti edustettuina.

Toinen ristiriita oli Väisäsen mielestä se, että ihmisten musiikille on ominaista se, että ihminen kykenee esittämään saman melodian eri sävelkorkeuksilta ja säilyttämään intervallisuhteet samoina eri korkeuksilla. Tämä taito puuttuu eläimiltä. Lisäksi eläinten äänelliset ilmaisumuodot eivät näytä kehittyneen samassa suhteessa kuin itse eläinlajit, joten ihmisen laulutaito on ominaista vain ihmisille eikä se ole sellaisenaan lajien kehityksen tulos.

Toisena Väisänen esittelee englantilaisen Herbert Spencerin teorian, jonka mukaan musiikki sai alkunsa ihmisen puheesta ja siinä esiintyvistä äänenkorostuksista ja tasovaihteluista. Varsinkin kiihtyneessä puheessa esiintyy sävelellisiä ominaisuuksia. Spencer jakaa musiikin synnyn lajit kahteen ryhmään. Puhuessaan lähellä oleville ihminen resitoi puheäänellä ja kauempana oleville ihminen huutaa tai huhuilee. Spencerin teorian hän tyrmää kuitenkin seuraavasti:

Kysymme näet: jos laulu olisi syntynyt puheesta, niin miten olisivat syntyneet luonnonkansoilla tavattavat n. s. pentatoniset sävelmät, joista puolet sävelaskeleet puuttuvat ja joitten melodia melodia usein liikkuu laajalla alalla? Ja vielä: se tosiasia, että näissä sävelmissä, kuten musiikissa yleensä, sävelsuhteet ovat matemaattisen tarkasti määrättävissä, osoittaa, että niiden synnyttäjä ei voi olla puhe, jossa äänitasosuhteet ovat hyvin häilyviä. Se, mikä musiikin puheesta olennaisesti erottaa, ei voi olla puheesta alkuisin. (Väisänen 1935: 126.) 
Pentatoniikka on siis keskeisessä asemassa olevana ilmiönä ratkaistaessa kysymyksiä musiikin alkuperästä. Kolmantena Väisäsen esittelemän musiikin synnyn selitystapana on niin sanottu rytmiteoria, jonka huomattavimmat edustajat ovat saksalaiset tutkijat Wallaschek ja Karl Bücher. Wallaschekin mukaan musiikki on syntynyt alkukantaisissa oloissa tanssin ja laulun yhteisvaikutuksesta sekä metsästyksen ja sodankäynnin yhteydessä pitämään esimerkiksi jonkin tietyn heimon ihmisiä yhtenä joukkona.

Väisäsen mukaan Bücher puolestaan lähtee ajatuksesta, jossa rauhanomainen työ ja sen suorittamiseen tarvittava liikunta on ollut lähtökohta taiteen ja myös musiikin syntymiselle. Ihminen rakensikin ensimmäiset työlaulunsa yksinkertaisia luonnonääniä jäljitellen eli samasta alkuaineesta, josta syntyivät myös sanat kieliin. Musiikki on kokonaisuudessaan siis kehittynyt nimenomaan työlaulusta, sillä työ ja säännelty rytmi on ollut yhteinen nimittäjä näille taiteen eri osille. Väisänen kritisoi Bücherin ajatuksia huomauttamalla, että yhteistyössä tehty työ ja sen synkronoiminen laululla liittyy pikemminkin kehittyneempiin oloihin kuin alkeellisiin oloihin. Esimerkkinä tällaisista ovat junttalaulut ja marssit. (Väisänen 1935: 126.)

Ensiksikin tuntuu olevan todellisuuspohjaa vailla ajatus, että kantaihmiset olisivat säännöstelleet ruumiinliikkeitään määrättyyn tahtiin tehdessään työtä jokapäiväisten elinehtojensa hyväksi. Alkeellisimmalla kehityskannalla olevat luonnonkansat tänä päivänä eivät tee töitään talkoissa ja laulaen, vaan yleensä elämän välttämättömyyksien mukaan. Heidän työnsä on epävakaata, huomispäivästä huolehtimatonta elintarpeiden keräilyä. (Väisänen 1935: 126.)

Suomessa tunnettujen musiikin syntyä pohtivien teorioiden lisäksi Väisänen esittelee artikkelissaan Carl Stumpfin näkemyksiä soveltaen niihin omia esimerkkejään ja mainiten, että juuri Stumpfin näkökantoihin hän itsekin yhtyy. Väisänen jatkaa Stumpfia mukaillen, että ihmisen on täytynyt tarvita säveliä jokapäiväisessä elämässään. Musiikin alku liittyy siten erityisesti huutoihin ja huhuiluihin ja juuri näihin liittyvä tarkoituksenmukainen viipyminen kiinteällä sävelellä tuotti periaatteellisesti oman tapansa tuottaa ääntä. Tämän perusteella Väisänen pitää kutsuhuutoja ja huhuiluja musiikkina eikä puheen lajina. (Väisänen 1935: 126.) Musiikin ja puheen välinen raja kulkee siis huhuilun ja puheen välissä.

Seuraavana asteena musiikin kehityksessä oli Väisäsen mukaan intervallien synty. Tämäkin liittyy ilmiönä merkinantohuutoihin mutta erityisesti sellaisissa tilanteissa, joissa huutoon osallistuu useampia ihmisiä. Monen ikäisten ja eri sukupuolta olevien ihmisten yhtäaikaisesta huudosta muodostuu luontevasti kuuluviin mitä 
erilaisimpia yhteissointuja. Jotta päästäisiin mahdollisimman kantavaan ja sointuvaan ääneen, on ihmisten täytynyt Väisäsen mukaan tuottaa mahdollisimman hyvin yhteensopivia ääniä ja siten alkaa suosia konsonansseja riitasointuisten intervallien sijaan. Siitä miten huudoista tuli musiikkia, piti Väisäsen mukaan huolen ihmiselle luonteenomainen uteliaisuus ja kokeilunhalu ja se, että musiikillinen ilmaisu tuotti ihmisille mielihyvää. Merkinantovälineinä alettiin käyttää myös erilaisia soittimia, muun muassa ruokopillejä, jotka eripituisina antavat eri sävelkorkeuden. (Väisänen 1935: 126.)

Ilmari Krohnin viimeinen musiikin alkuperää ja siten myös pentatoniikkaa sivuava artikkeli on "Vanhojen kansojen musiikista" (Krohn 1937: 9-10). Hänen näkemyksekseen näyttää vakiintuneen Spencerin tapaan ajatus siitä, että musiikin alku liittyy toisaalta merkinantohuutoihin, toisaalta uskonnollisen hartauden harjoittamiseen. Merkinantohuuto vaatii laajempia intervalleja (kvartteja, kvinttejä) ja siksi pentatoniseen asteikkoon pohjautuvaa laajaliikkeistä sävelkieltä. Pentatoniikan tiedettiin olevan vallalla Itä- ja Pohjois-Aasian kansoilla, intiaaneilla, eskimoilla, lappalaisilla, eräillä Itä-Venäjän turkin- ja suomensukuisilla heimoilla (esim. tšeremisseillä) sekä pohjakerrostumana kelttiläisten ja unkarilaisten kansanmusiikissa. Resitatiivin eli sävelsanailun melodinen idea liittyy puolestaan asteittaiseen liikkeeseen.

On hieman yllättävää, että suomalainen pentatoniikkaa sivuava keskustelu perustui vielä 1930-luvulla sangen vanhoihin 1890-luvun ajatuksiin. Syynä tähän voidaan olettaa olleen ainakin Ilmari Krohnin ankaran suhtautumisen vertailevan musiikkitieteen tutkimustuloksiin, joissa eri kansojen musiikeissa tulkittiin esiintyvän erilaisia säveljärjestelmiä yhden universaalin säveljärjestelmän sijaan. Tästähän Krohn sanoutui selkeästi irti vuoden 1916 Sävelopissaan. Tämän ajattelun vaikutuksen voi havaita myös siinä, että Krohn, Launis ja Väisänen pitäytyivät kaikki tiukan duurimolli-tonaalisissa tulkinnoissa tutkiessaan eri kansojen kansansävelmiä. Huomiota herättää sekin, ettei Pohjois-Amerikan alkuperäisväestön musiikkiperinteiden erittäin laajalla ja monipuolisella 1900-luvun alkupuoliskon tutkimuksella näytä olleen juurikaan vaikutusta suomalaiseen pentatoniikkaan liittyvän pohdintaan.

On mielenkiintoista huomata, että vaikka musiikinteoreettisissa kysymyksissä Krohnilla oli monia näkemyseroja varsinkin amerikkalaisten tutkijoiden kanssa, Krohnin työ voidaan liittää osaksi vertailevan musiikkitieteen tutkimuskenttää (Krohn 1916: 9). Näkemyserot eivät myöskään olleet esteinä suomalaisten tutkijoiden yhteyksiin ulkomaille. Konferenssimatkojen lisäksi Krohn ja Väisänen raportoivat esimerkiksi Musiikkitieto-lehdessä tämän tästä musiikintutkimuksen kansainvälisis- 
tä tapahtumista. Vuonna 1910 Krohn perusti Suomeen Internationale Musikgesellschaftin alaosaston, jonka pohjalta syntyi Suomen Musiikkitieteellinen Seura vuonna 1916 (Vainio 2003: 362).

Vuonna 1928 aloitti toimintansa Kansainliiton yhteydessä toimiva Henkisen työn tekijäin järjestö, jonka toimintaan Krohn myös osallistui (Krohn 1935: 59). Väisänen vieraili Neuvostoliitossa, Leningradissa vuonna 1937 ja Saksan musiikintutkimuksen valtionlaitoksessa sota-aikana vuonna 1942. Laitoksen johtaja tri F. Bose oli vieraillut Suomessa äänittämässä Karjalassa vuonna 1936 (Väisänen: 1945: 112-114; 1943: 59).

Erityistä huomiota herätti sekä saksalaisen tutkimuksen ohella Unkarissa tapahtunut tutkimus. Béla Bartókin tutkimusmetodi oli kehitetty 1920-luvulla osittain Ilmari Krohnin niin sanotun kadenssimenetelmän pohjalta. Väisänen $(1938 ; 1944)$ kommentoi Béla Bartókin ja Zoltán Kodályn tutkimusta ja otti kantaa myös pentatoniikkaan ja sen varhaisen unkarilaisen musiikin edustavuutta liittyviin kysymyksiin. Myös A. O. Väisänen (esim. 1934; 1965) käsitteli suoranaisesti pentatonisia aineistoja lukuisissa kirjoituksissaan.

\section{Päätelmä}

Käsitteenä pentatoniikka on ollut tunnettu Suomessa mitä todennäköisimmin jo 1800-luvulla. Se oli kuitenkin lähinnä tuttua kirjallisuudesta, ei soivana musiikkina. Ensimmäisen kerran pentatonisen musiikin toivat konkreettisesti suomalaisten musiikintutkijoiden tietoon Armas Launis ja Väinö Salminen. Nämä aineistot julkaistiin Launiksen nuotinnoksina vuoden 1908 Lappische Juoigos-Melodien -kokoelmassa. Launiksen työ on varhainen esimerkki itse kerätystä laajasta aineistosta, josta tutkija-kerääjä "löysi" merkittävän pentatonisen säveljärjestelmän perustan. Juuri varhaisen ajankohtansa vuoksi Launiksen työ ansaitsisi tulla mainituksi nykyistä useammin koko etnomusikologian tieteenalan oppihistoriassa.

Asiakokonaisuuden kannalta tarvittaisiin kattava selvitys siitä, mikä osa 1800-luvun tutkimuskirjallisuudesta oli todella tunnettua Suomessa, jotta voidaan vastata kysymykseen, milloin ensimmäisen kerran suomalaisessa musiikintutkimuksessa käytettiin pentatoniikka-termiä. Näihin kysymyksiin vastaaminen vaatii kuitenkin muun muassa 1800-luvun loppupuolen sanomalehtiaineiston kattavan analyysin. Oman ongelmansa muodostaa se, että 1900-luvun alkupuolen kirjoituksissa viitataan sangen harvoin muuhun tutkimukseen. Tästä johtuen suomalaisessa musii- 
kintutkimuksessa käytettyjen ajatusten alkuperien selvittäminen vaatii yleisemmän vertailun suomalaisen ja ulkomaisen aikalaistutkimuksen välillä.

1800-luvun riemannilainen musiikintutkimus muodostaa keskeisimmän lähtökohdan suomalaiselle pentatoniikkaa koskevalle pohdinnalle ja on varsin todennäköistä, että sieltä omaksuttiin myös pentatoniikan käsite Suomeen. Suomessa pentatoniikka ymmärrettiin ensisijaisesti duuri-molli-tonaliteetin osana, ei itsenäisenä säveljärjestelmänä. Pentatoniikka oli siten lukuisten 1800-luvun musiikinteoreettisten pohdintojen tavoin aukollista tai vajaata diatoniikkaa. Toisaalta juuri duurimolli-tonaaliset sävelfunktiot mahdollistivat pentatoniikan tunnistamisen esimerkiksi pohjoissaamelaisista joikusävelmistä, joista huomattavassa osassa ei ollut edes lähtökohtaisesti pentatoniikka-käsitteen oletuksen mukaista viittä säveltä vaan ne olivat säveliköiltään suppeampia.

Pentatoniikka kytkeytyi jo varhaisessa vaiheessa musiikin alkuperää ja syntyä koskeviin pohdintoihin ja näihin liittyviin kulttuuriteorioihin, joista merkittävimmässä asemassa on ollut ajatus kulttuurievoluutiosta. Tämä vaikutus näkyy laajemminkin kuin vain darwinistisesti ajattelevien tutkijoiden kirjoituksissa. Kulttuurin kehityksen yleinen idea läpäisee lähes kaiken kulttuurin alkuperää pohtivan teoreettisen kirjallisuuden. Pentatoniikan erityinen piirre on kuitenkin se, että silloin kun sitä tavattiin "primitiivisten" kansojen musiikeissa, niin se lähes poikkeuksetta yhdistettiin koko kulttuuria koskevaan evolutionistiseen määrittelyyn.

1900-luvun ensimmäisellä vuosikymmenellä käytettiin yleisesti esimerkiksi "raakalaiskansat"-nimitystä Euroopan ulkopuolisista kansoista. Termin tilalle tuli 1910-luvulla "luonnonkansat" samaan aikaan kun tutkijoiden käyttöön alkoi tulla entistä enemmän tietoa näistä kulttuureista ja musiikeista. On kuitenkin hieman yllättävää, että musiikin varhaisvaiheisiin liittyvä pohdinta ilmestyi toden teolla Krohnin ja Väisäsen kirjoituksiin vasta 1930-luvulla ja tuolloinkin he referoivat 1800-luvun lopulla käytyä keskustelua. Selvitettäväksi jääkin kysymys siitä, mikä oli 1900-luvun ensimmäisinä vuosikymmeninä vertailevan musiikkitieteen ulkomaisten tutkimustulosten todellinen vaikutus suomalaiseen musiikintutkimukseen.

Käsittelemieni lähteiden valossa Krohnin universaali musiikinteoria ja hänen kielteinen suhtautumisensa teoriaan eri kulttuureissa tavattavista erilaisista säveljärjestelmistä hidasti ulkomaisten vaikutusten leviämistä Suomeen. Samoin lisäselvitystä kaipaa se, mikä oli 1900-luvun alkupuolella kerättyjen ääniteaineistojen tosiasiallinen vaikutus kansanmusiikintutkimukseen. Suomen ulkopuolellahan juuri äänitteet olivat keskeisessä uudistavassa roolissa sekä yleisessä musiikintutkimuk- 
sessa että myös pentatoniikkaan liittyvässä tutkimuksessa.

Pentatoniikan käyttöyhteydet sijaitsivat eurooppalaisen taidemusiikin teorian kannalta marginaalissa. Toisaalta juuri kehitysopillisesti mahdollisimman varhaisiksi oletettujen musiikkien avulla pyrittiin ratkaisemaan kysymyksiä kaiken musiikin alkuperästä ja juuri tämän tutkimuksellisen tehtävän vuoksi luonnonkansojen musiikki sekä pentatoniikka saavat huomattavan tutkimuksellisen roolin. Taidemusiikin ja luonnonkansojen musiikkien välissä oli tutkimuksellisesti muu eurooppalainen kansanmusiikki. Tämä vaatii oman tarkastelunsa mutta hypoteeseina voidaan pitää sitä, että näiden aineistojen käsittelyssä variaatio alkukantaisten ja kehittyneiden musiikillisten elementtien välillä on paljon suurempi kuin luonnonkansojen musiikkien tutkimuksessa. Lisäksi eri valtioiden kansalliset näkökulmat ovat varmasti vaikuttaneet kansallisten kansankulttuurien ja kansanmusiikkien arvottamiseen.

Toisaalta voidaan sanoa, että pentatoniikka oli ensimmäinen yhtenäinen musiikkia koskeva rakenneanalyyttinen malli, jolla pystyttiin käsittelemään esitonaalisiksi määriteltyjä musiikkeja erilaisilta maailman kansoilta. Duuri-molli-tonaalisuushan oli varattu vain kulttuurikehityksen huipulla oleville eurooppalaisille.

Alussa esittelemäni tämän päivän pentatoniikka-määritelmiin kuuluvat ajatukset saavat täsmällisemmän merkityksen tarkasteltaessa pentatoniikka-käsitteen varhaisvaiheita. Ajatus siitä, että pentatoniikka on merkki varhaiskantaisesta musiikista, on lähtökohtana 1800-luvun lopun ja 1900-luvun musiikintutkimuksessa. Vastaavasti pentatoniikka hahmotettiin jo varhain pianon mustien koskettimien sävelavaruudeksi sijoittamalla se tasavireiseen ja duuri-molli-tonaaliseen viitekehykseen. Oman pohdinnan arvoinen kysymys on kuitenkin se, että hyväksyykö nykyinen tutkimus todellakin kaikki ne perustelut, joiden avulla pentatoniikkaan liitetyt yleisemmät tulkinnat on aikoinaan määritelty.

\section{Kirjallisuus}

Boas, Franz (1888) The Central Eskimo. Washington: Bureau of American Ethnology.

Crowdery, James R. \& Blažeković, Zòvrako \& Brook, Barry S. (2004) Speaking of Music: Music conferences, 1836-1966. Eds. James R. Crowdery, Zdravko Blažeković \& Barry S. Brook. New York: Répertoire International de Littérature Musicale (RILM).

Day-O'Connell, Jeremy (2002) "Pentatonic". The New Grove Dictionary of Music and Musicians. Second Edition. Ed. Stanley Sadie. London: MacMillan Publishers Limidet. Ss. 315-317.

Ellingson, Ter (1992) "Transcription". Ethnomusicology. An introduction. Ed. Helen Myers. New York: W. W. Norton. Ss. 110-152.

Ellis, Alexander J. (1885) "On the Musicial Scales of Various Nations". Journal of the Society of Arts, 
xxxiii. 3/27: Ss. 485-527; 10/30: Ss. 1102-1111.

Engel, Carl (1864) The Music of the Most Ancient Nations, particularly of the Assyrians, Egyptians and Hebrews. London.

Fétis, Francois Joseph (1869-76) Histoire générale de la musique depuis les temps les plus anciens jusqu'à nos jours. Paris: Firmin-Didot.

Helmholz, Hermann, L. F. (1954) On the Sensations of Tone. As a physiological basis for the Theory of Music. New York: Dover Publications Inc.

Huttunen, Matti (1993) Modernin musiikinhistoriankirjoituksen synty Suomessa. Acta Musicologica Fennica 18. Helsinki: Suomen Musiikkitieteellinen Seura.

Jouste, Marko (2001a) "Saamelaiskuvauksen teemoja suomalaisessa joikututkimuksessa". Musiikin suunta 2001/1, ss. 6-27.

Jouste, Marko (2001b) "Porosaamelaisjoiun säveljärjestelmän piirteitä". Etnomusikologian vuosikirja 13. Toim. Jarkko Niemi. Helsinki: Suomen etnomusikologinen seura. Ss. 142-160.

Jouste, Marko (2004) "Armas Launiksen vuoden 1904 Lapin matkan joikusävelmien keräys ja soiva vertailuaineisto". Musiikin suunta 2004/2, ss. 58-81.

Joutsenvirta, Aarre \& Perkiömäki, Jari (2008) Musiikinteoria 1/ Asteikot ja soinnut. Helsinki: SibeliusAkatemia. <http://www2.siba.fi/muste1/index.php?id=22\&la=fi> (luettu 29.7.2008).

Klemetti, Heikki (1922) Musiikin historia. I osa. Toinen painos. Porvoo: WSOY.

Krohn, Ilmari (1901) "Kansansävelmien alkuperästä". Valvoja 1901. Ss. 549-558.

Krohn, Ilmari (1911) "Suomalaiset kansansävelmät". Oma maa. Tietokirja Suomen kodeille. Toim. Edvin Linkomies. Porvoo: WSOY. Ss. 498-514.

Krohn, Ilmari (1913) "Luonnonkansojen musiikki". Tietosanakirja V osa. Helsinki: TietosanakirjaOsakeyhtiö.

Krohn, Ilmari (1916) Musiikin teorian oppijakso II. Säveloppi. Porvoo: WSOY.

Krohn, Ilmari (1922) "Suomalaiset kansansävelmät". Oma maa. Tietokirja Suomen kodeille. Toim. Edvin Linkomies. Toinen, uudistettu painos. Porvoo: WSOY.

Krohn, Ilmari (1935) "Kansansävelmäin tutkimus kansainvälisellä pohjalla". Musiikkitieto Maaliskuu 1935. Ss. 59.

Krohn, Ilmari (1937) "Vanhojen kansojen musiikista". Musiikkitieto 9-10/1937, ss. 146-151.

Laitinen, Heikki (2003) "Laulu muistinvaraisessa kulttuurissa". Iski sieluihin salama - kirjotuksia musiikista. Toim. Hannu Tolvanen \& Riitta-Liisa Joutsenlahti. Suomalaisen Kirjallisuuden Seuran toimituksia 942. Helsinki: Suomalaisen Kirjallisuuden Seura. Ss. 289-302.

Launis, Armas (1904) "Kertomus sävelkeruumatkasta Norjan ja Suomen Lapissa kesällä 1904". Suomi IV:3.

Launis, Armas (1905) "Kertomus sävelkeruumatkasta Norjan ja Suomen Lapissa kesällä 1905". Suomi IV:4.

Launis, Armas (1907a) "Lappalaisten joikusävelmät I". Säveletär 1907 nro 3. Ss. 37-39.

Launis, Armas (1907b) "Lappalaisten joikusävelmät II". Säveletär 1907 nro 4. Ss. 53-55.

Launis, Armas (1907c) "Lappalaisten joikusävelmät III". Säveletär 1907 nro 5. Ss. 72-76.

Launis, Armas (1908) Lappische Juoigos-Melodien. Suomalais-Ugrilaisen Seuran Toimituksia XXVI. Helsinki: Suomalais-Ugrilainen Seura.

Launis, Armas (1909) "Die Pentatonik in den Melodien der Lappen". Haydnzen Tonfeier III. Kongress der Internationalen Musikgesellschaft. Wien.

Launis, Armas (1986) "Kertomus sävelkeruumatkasta Norjan ja Suomen Lapissa kesällä 1904 ja 1905". Kansanmusiikki 2/86, ss. 14-24.

Launis, Armas (2004) Tunturisävelmiä etsimässä Lapissa 1904 ja 1905. Toim. Minna Riikka Järvinen. Suomalaisen Kirjallisuuden Seuran Toimituksia 991. Helsinki: Suomalaisen Kirjallisuuden Seura.

Nettl, Bruno (1956) Music in Primitive Culture. Cambridge: Harvard University Press.

Pekkilä, Erkki (1984) "Historiallinen katsaus analyysimetodiikan kehitykseen etnomusikologiassa". Musiikki 1984/3-4, ss. 129-187.

Powers, Harold (1992) "Modality as a European cultural construct". Secondo convegno europeo di 
analisi musicale. Eds. Rosanna Dalmonte \& Mario Baroni. Trento: Università degli studi di Trento, Dipartimento di storia della civiltà europea. Ss. 207-219.

Rehding, Alexander (2003) Hugo Riemann and the Birth of Modern Musical Thought. Cambridge: Cambridge University Press.

Sachs, Curt (1962) The Wellsprings of Music. Ed. Jaap Kunst. New York: Da Capo Press.

Salminen, Väinö (1906) "Lappalaisista joikauksista". Suomalais-Ugrilaisen Seuran Aikakauskirja XXIII, 30. Ss. 1-8.

Salminen, Väinö (1907) "Lappalaisten 'joikaus'-lauluista". Valvoja 27: 1. Ss. 1-9.

Salminen, Väinö (1907) "Havaintoja Kemi-, Ounas- ja Muonionjokilaaksoon kesällä 1904 tehdyltä runonkeräysmatkalta". Suomalais-Ugrilaisen Seuran Aikakauskirja XXIV, 3. Ss. 4-20.

Spencer, Herbert (1890) "The Origin of Music". Mind, vol. 15, No. 60 (Oct., 1890). Ss. 449-468.

Sävelten maailma V (1994) "Pentatoniikka". Toim. Jukka Isopuro \& Kimmo Korhonen. Helsinki: WSOY. Ss. 218.

Törnudd, Aksel (1907) Musiikinhistoria pääpiirteissään seminaareja ja musiikinharrastajia varten. Helsinki: Otava.

Vainio, Matti (2003) "Suomalainen musiikki tutkimuskohteena". Johdatus musiikintutkimukseen. Toim. Tuomas Eerola, Jukka Louhivuori \& Pirkko Moisala. Helsinki: Suomen Musiikkitieteellinen Seura. Ss. 359-369.

Väisänen, A. O. (1934) "Näytteitä vogulien pentatonisista sävelmistä". Musiikkitieto 5. Ss. 74.

Väisänen, A. O. (1935a)"Musiikin synty". Musiikkitieto 7/1935, ss. 126-127.

Väisänen, A. O. (1935b) "Musiikin synty II". Musiikkitieto 8/1935, ss. 138-139.

Väisänen, A. O. (1938) "Unkarilaisesta kansanmusiikintutkimuksesta - Selostusta ja huomioita". Musiikkitieto marraskuu 1938. Ss. 121-123.

Väisänen, A. O. (1941) "Saksalaisen ja suomalaisen kansanlaulun alkumuotojen selityskoe". Musiikkitieto joulukuu 1941, 151. Ss. 9-10.

Väisänen, A. O. (1943)"Kansanmusiikintutkimuslaitos Berliinissä". Musiikkitieto huhtikuu 1943. Ss. 59.

Väisänen, A. O. (1944) "Onko Suomella ja Unkarilla yhteisiä sävelperuja?" Musiikkitieto marraskuu 1944. Ss. 120-121.

Väisänen, A. O. (1945) "Neuvostoliiton tiedeakatemian fonogrammiarkisto". Musiikkitieto lokakuu 1945. Ss. 112-114.

Väisänen, A. O. (1965) "Über die Pentatonik in der Finnisch-ugrischen Volksliedern". Congressus internationalis Fenno-Ugristarum (1965) Congressus secundus internationalis Fenno-Ugristarum: Helsingiae habitus 23.-28.8.1965. Pars 2 : Acta ethnologica. Helsinki: Societas Fenno-Ugrica.

Wallaschek, Richard \& Cattell, James McKeen (1891) "On the Origin of Music". Mind, vol. 16, No. 63 (Jul., 1891). Ss. 375-388.

Wallaschek, Richard (1970) Primitive music. An inquiry into the origin and development of music, songs, instruments, dances and pantomimes of savage races. New York: Da Capo Press. 